\title{
alternative strategies in the american peace movement in the 1920's
}

\section{charles de benedetti}

The principal preoccupation of the American peace movement in the 1920's was the re-definition of the nation's role in European affairs. Horrified by the destructiveness of the World War, American peace groups were determined to prevent the recurrence of violence among the advanced industrial powers who anchored the European state system. Force as an instrument of policy among the powers was demonstrably catastrophic. At the same time, American peace elements felt certain that the realization of their hope depended upon the moral and physical strength of the United States. Consciously "America-centric," post-war peace activists assumed that questions of war and peace in modern industrial civilization turned upon the decisions of the American
It is perhaps true that the path to internationalism through small states is dangerous and uncertain; but, paradoxical as it may seem, internationalism can rest only on satisfied nationalism. The sentiment is intractable and compelling, and cannot be removed from politics unless it is recognized; peoples whose aspirations have long been thwarted will not be satisfied with anything short of self-determination. . . . International law depends for its validity upon the agreement of sovereign states, and it will continue to be weak in proportion to the number of states whose agreement is necessary.

We are forced, therefore, to accept the anomaly of an increase in the number of nation states, at the same time that we are attempting, by an international league, to lay a stable basis for the federation of the world. Lindsay Rogers, "The League of Nations and the National State," in Stephen P. Duggan (ed.), The League of Nations: The Principle and the Practice (Boston, 1919), 86-87.

people. It was for this reason that they debated vigorously the comparative value to American policy and world peace of the League of Na- 
tions, the World Court, arbitration treaties, collective sanctions and the outlawry of war. Yet even these issues, in the end, were no more than variants of one elemental question: how could the United States most satisfactorily introduce discipline in European politics?

Three alternative strategies arose in the post-war peace movement in response to that question. Although they are categorized here as legalist, reformist and functionalist, the strategies were by no means mutually exclusive. Proponents of one often collaborated with advocates of another. Moreover, none of the strategies was ever developed with deliberateness or articulated with precision. The premium in the post-war movement was upon action and not contemplation. Nevertheless, alternative strategies were recognizable. Each was distinguished by a unique understanding of the nature of peace. And each was animated by the mixed ideological commitments that men bring into movements.

The legalist tradition was more than an ideology or a movement. It was an ethos that suffused the thinking of a significant number of postwar peace leaders. ${ }^{1}$ Organized in associations like the American Peace Society, the Carnegie Endowment for International Peace and the American Society of International Law, supporters of a legalist approach to world politics perceived peace as a state attendant upon the triumph of justice. Legalist spokesmen like Arthur Deerin Call, executive secretary of the American Peace Society, and Dr. James Brown Scott, an authority on international law and an officer of the Carnegie Endowment, held that the achievement of peace was contingent upon the extension of justice throughout international politics. The extension of justice, in turn, consisted of the codification by experts of international rules of equity, the application of these rules by an international court of justice, and final acceptance by litigants respectful of the sanction of world public opinion. Through a tightening web of procedure, substantive "legal justice" would gradually be gained and peace assured. Legalists made it clear that they did not seek the "abstract justice" of "the reformer and the idealist," but the "legal justice" of courts and codes that could be "counted upon to function with certainty" in minimizing the possibilities of future war. ${ }^{2}$ Frightened by the antinational, class appeal of Lenin's "Mundanism," they were determined to solidify the modern state system and existing property relationships by purging the Old Order of its failings through the instruments of enlightened judicial leadership. Peace was reached through the slow, deliberate procedures of the courts and "by making the law itself its own best argument for obedience." 3 It was a trying, trial process and decidedly not one for the impatient. People must not measure "the progress of nations by the foot-rule of our short lives," warned the venerable Elihu Root. "You must think in terms of generations and centuries." 4 
Legalism essentially represented the views of a conservative elite who wielded the scepter of law against the twin dangers of international violence and social convulsion. Fearful of the alarming unpredictability of Old World politics, legalists opposed American involvement in European affairs and supported the preservation of complete freedom of action throughout the world. Any revision of America's traditional posture of "interested isolation" in world affairs was "unnecessary and unlikely." 5 Legalists reasoned that the Monroe Doctrine had irrevocably divided Europe and America into separate spheres. Its century-long success had permitted the United States to gravitate toward a polity of law while the European system had stagnated in conflict and violence. ${ }^{6}$ In conjunction with this belief, legalists feared that embroilment in European politics would sharpen tensions among ethnic groups and unsettle social stability within the United States. David Jayne Hill stated solemnly that American intervention in Old World affairs "would result in divisions that would be deeper than they are now and involve our Government in constant domestic turmoil; for it is not realized in Europe that we have in the United States all the races, all the race affections, and all the race prejudices that exist in Europe." 7 Among legalists everywhere, there was little doubt that the risks implicit in active American participation in European politics outweighed any possible gain.

While the United States must avoid entanglement in Old World politics, it could nevertheless contribute to Europe's pacification by universalizing the principles of the American judicial system. Legalists commonly contended that the foundation of the American constitutional system lay in the power of the Supreme Court to adjudicate vital differences among sovereign states. Indeed it was in the practical validation of the principle "that when any one of the states becomes recalcitrant, it shall be coerced by law" that America had made its "supreme contribution to world peace." 8 Without physical force, the Supreme Court successfully applied the rule of law among rival states. It was the paragon of judicial order, the basis for a world founded on law and justice. The hope of peace among civilized states rode upon the internationalization of its principles and the elevation of the whole Anglo-American legal experience to world practice. $^{9}$

Thus the purpose of legalist peace action was to urge the structuring of European politics along juridical lines inspired by the American experience. Legalist leaders supported efforts to collaborate in the codification of international law and favored American accession to the World Court. They also expressed great interest in bringing about the convocation of a Third Hague Conference. Legalists at no time, however, permitted policy preferences to lead them into support of mass action campaigns. Rather than organize popular support, they preferred to sponsor legal research and cooperate closely with government officials. "After 
all," Arthur Deerin Call told the directors of the American Peace Society, "the greatest peace society with which we are permitted officially to associate is the United States Government."10 As Washington progressed in its pursuit of liberty under law, the blessings of order, peace and prosperity would spread to embrace all peoples.

While legalists identified peace with triumphant justice, other peace groups saw their goal as the simple absence of war. The social reformers who headed pacifist, church and women's organizations understood peace as the condition that followed upon the destruction of the war system. "Peace means getting rid of war," the Reverend John Haynes Holmes said firmly, "and getting rid of war means outlawing it along with piracy, the duel, and the saloon."11 The reformist strategy was distinguished by the assumption that war was a crime, a collective sin, a hideous institution that blocked man's access to the humane, Christian life. "Each age faces one supreme moral issue," said Sherwood Eddy, a leading preacher of the Social Gospel. "For our time that issue is war. It is Caesar or Christ, man's way or God's, the appeal to force as ultimate power or to organized goodwill, war or peace."12 Frustrated by the failure of a war to end war, reformist leaders intended to subject the monster to the grinding power of American social reform.

Reformists throughout the decade invested great faith in the progressive importance of law. Fresh from the hard-won victories of prohibition and women's suffrage, they shared the legalist confidence in the superiority of American constitutionalism. Unlike the legalists, however, reformists identified the strength of American law not in its sanction for order as much as in its capacity to liberate men's minds from prejudice and to abolish pernicious social institutions. "Making war illegal seems a long way off," the pacifist Sidney Strong told Senator William E. Borah. "So once did slavery and the saloon seem eternal, but I've seen them pass."13 A press release from the Women's Peace Union of the Western Hemisphere expressed the same sense of reform progression, along with the sexual consciousness that actuated feminist peace leaders in the 1920's: "Women won suffrage. Women won prohibition. Now women are putting through the outlawry of war."14

Reformists agreed that the United States possessed the spiritual energy and material resources needed to suppress the institution of war. But they differed in their analyses of Europe's problems and in their plans for adapting America's strength to European needs. Most reformists identified Europe's post-war malaise as a spiritual exhaustion that had been compounded by social and economic dislocation. They therefore exhorted the American people to transfuse part of the country's abundant spiritual vitality to the Old World through lines of trade and law. Disclaiming any interest in the politics of foreign policymaking, the great majority of reformists worked to rouse popular sentiment behind a variety of non-entangling actions that would re-inflate Europe's confidence and "stabilize the world."15 
In practice, the reformist strategy operated through several educational and organizational enterprises. In 1921 the Federal Council of Churches of Christ in America announced plans to lead its twenty million constituents upon a Ten-Year Crusade for a Warless World. Through its Commission on International Justice and Goodwill, the Federal Council proposed to shift modern international relations from a "warsystem" to a "peace-system" by generating enlightened public opinion and by exalting juridical substitutes for war. The Church Peace Union was equally interested in changing the "state of mind that now condones war"; and it actively assisted the World Alliance for International Friendship Through the Churches in sharpening antiwar sentiment among Protestant clergymen. ${ }^{16}$ Among secular organizations the National Council for Prevention of War took the lead in trying to activate business, labor and farm groups in a united front against war. The National Committee on the Cause and Cure of War assembled nine national women's organizations into a lobby for study and action, while pacifists gathered in the Women's International League for Peace and Freedom and the Women's Peace Union. ${ }^{17}$ G. Sherwood Eddy and Kirby Page spread the doctrine of Christian pacifism and international cooperation across college campuses through the agency of the YMCA. The Fellowship of Reconciliation and the War Resisters League sustained those who chose to renounce forever individual participation in the war system. In meeting after meeting, pacifists, churchmen and women's groups resolved their commitment to Christian understanding, the World Court, disarmament, the outlawry of war and even (upon rigid conditions) the League of Nations. ${ }^{18}$ Propagandizing and organizing, they hoped to calm Europe by creating in America a wave of moral unanimity that would smash the war system and uncover the foundations of lasting peace.

Several reformists dissented, however, from the majority position. Led by Bull Moose veterans like Raymond Robins, an influential reformist minority blamed Europe's discontent upon reactionary leadership and volatile class divisions. Minority spokesmen were deeply concerned with America's vulnerability to continued European wars. But they resented efforts to excite Americans into concern with Europe on the grounds that the prosecution of an active foreign policy would result in the nation's absorption in the corrupt politics of the Old Diplomacy. The philosopher John Dewey captured the progressive dilemma in these terms:

... while our day of isolation is over, international affairs are still conducted upon a basis and by methods that were instituted before democracy was heard of as a political fact. Hence we engage in foreign policies only at the risk of harming even such imperfect internal democracy as we have already achieved. ${ }^{19}$

Distrustful of Europe and fearful of new wars, reformists like Dewey demanded that the American government lead an attack upon the legal 
underpinnings of the war system. Dissident progressives pressed insistently for the outlawry of the lawful institution of war and for the establishment of an international Supreme Court to settle disputes. By purging war from the body of international law, outlawry enthusiasts intended to expose war in its criminal infamy, smash the Old Diplomacy and render American-made law the prescriptive pattern of international behavior. It was a large, perhaps laughable order. But it appeared to many post-war progressives as the most effective way of purifying European politics and making the world safe for America. ${ }^{20}$

Despite the minority fears, the larger reformist strategy never envisioned an active American role in European politics. When they spoke of international organization and substitutes for war, reformists thought of juridical devices and developing bonds of moral sentiment. They expected the United States to assume an exhortatory, pontifical role in Europe that would bring Europe moral uplift and political tranquillity. But they regarded the total displacement of the war system as an arduous process that the American people could best promote by retaining their youth, enthusiasm and independence. As the slogan of the National Council for the Prevention of War put it, " 'America First'-In the Crusade for a Warless World."'21

Finally, leaders of organizations like the League of Nations NonPartisan Association, the Foreign Policy Association and the World Peace Foundation favored a functional approach to world politics. Conceiving of peace as an ongoing process, functionalists maintained that the very fragility of modern industrial civilization demanded the institutionalization of managerial controls over international affairs. Columbia University history professor James T. Shotwell believed, for example, that "peace does not mean merely the abstention from war, it means as well the maintenance of those conditions under which civilization can endure and develop." 22 Peace was a problem of management. It was a problem of rationalizing techniques which would refine European politics by excluding irresponsible violence.

The drive to rationalize the processes of European politics grew with the realization that science and technology had multiplied the scope and destructiveness of modern war by unanticipated proportions. Each new invention, each scientific advance moved industrial civilization further from human control and toward a terrifying momentum of its own. Raymond B. Fosdick, a former assistant secretary of war and a leading exponent of the League of Nations, felt that "the whole world is tottering on the edge of an abyss. Modern science has put us in a position where with another outburst of passion, ... . we can destroy all the values that have been painfully built up in the last thousand years. The race never had such weapons before, and our situation is entirely new in history." 23 Shotwell and Fosdick agreed. Without organization, without systematic 
direction by "creative scientific intelligence," runaway technology would "bury this thing we call civilization in a grave too deep for resurrection." 24

Spreading along lines of industrial interdependence, modern total war promised to trap the United States and all others in its fury. Functionalists looked back upon Wilson's futile attempt at war-time neutrality as ample proof of the precariousness of the American position. They furthermore anticipated that the growing importance and complexity of international commerce would only heighten the nation's vulnerability. Certain that America could not escape the epidemic violence of modern war, functionalists demanded that Republican policymakers cease the evasion of unilateralism and confront directly the unavoidable question: how could the United States order international relations in a way that would dampen national rivalries before they inflamed the lines of interdependence and sucked America into conflict? The nation seemed to possess little real choice. Certainly James G. McDonald, chairman of the Foreign Policy Association, thought that the matter was clear: "We may not like European entanglements, and I don't like them myself, but when forces are in operation which will inevitably create entanglements and difficulties, I prefer assuming responsibility for positive effort to avoid them rather than to assume responsibility for inaction."25 For its independence as well as its safety, America must take the lead in rationalizing and maintaining a "definitized" world order. ${ }^{26}$

Functionalists placed their highest hopes for the creation of a "definitized" world order in the League of Nations and its associated agencies. For one thing, the League promised to absorb the gnawing insecurity and overcome the disorganization that together were at the bottom of Europe's discontent. By systematizing international diplomacy through continuing conferences and committees, the League apparatus would create techniques that enveloped the threat of violence in folds of investigations and reports. The League appeared as "an essentially European organization" that substituted conference, arbitration and "the ordinary processes of civilized governments" for the uncontrollable destructiveness of war. ${ }^{27}$ In this same vein, the League represented a unique laboratory for experimentation in human and institutional cooperation. It was potentially the most attractive proving ground for the work of social engineers. And social engineers, functionalists maintained, were truly those figures who commanded the levers of future world progress. "The sword won't do the job any more," exclaimed the historian Charles A. Beard.

The social engineer is the fellow. The old talk about sovereignty, rights of man, dictatorship of the proletariat, triumphant democracy and the like is pure bunk. It will not run trains or weave cloth or hold society together. ${ }^{28}$

At the same time, functionalists believed that the League served splendidly to amplify America's voice in European affairs. The United 
States had no interest in strictly European affairs, they agreed, for America was more than a European power. But America did have an interest in avoiding involvement in unnecessary wars and in maintaining a prosperous international trading community. The nature of the nation's interests thus required that it assume an active advisory role in matters of international importance. Arthur M. Sweetser, a former Boston newsman and a prominent official in the League Secretariat, ably expressed the functionalist position as early as 1920. America, he declared, was "the greatest cohesive political unity in existence, the richest nation in the world, the most highly organized," and the one whose "ideals and principles" flourished best by "showing them to the whole world and urging other nations to follow them." This did not mean, however, that America must concern itself with the petty disputes of others. "I mean quite on the contrary," said Sweetser, "that she should be ever ready, in a strategic position, where, when an issue arises which is worthy of her participation, she should be able to express herself and express herself fruitfully. I cannot believe that any American wishes this country to be mute in the world's great struggle of ideas." 29 The League obviously provided the most suitable forum for America's purposes. Although a European combine, it offered a boardroom in which the United States could successfully discharge its consultative responsibility in the management of peace.

The functionalist campaign to streamline international relations by affirming America's advisory leadership took place along many fronts. The World Peace Foundation and the Foreign Policy Association sponsored programs to gather and disseminate facts which emphasized the intricate interdependence of modern international relations. The League of Nations Non-Partisan Association propagandized directly for public support of American entrance into the League. It subsidized speakers, published and distributed literature and formed local cells across the United States. In addition, pro-League leaders tried to affect national policy by staffing governmental committees of inquiry on international affairs and by influencing friendly Administration officials. Functionalists also worked to establish a network of cooperation among European peace leaders who shared their belief in the need for the rapid rationalization of international politics. The Division of Economics and History of the Carnegie Endowment supervised the formation in Europe of several national committees of scholars and industrial experts, who were charged with providing their respective governments with technical data on matters of disarmament and security. The Institute of International Education acted as a service center for the exchange among countries of scholars and students. And the International Committee on Intellectual Co-operation, first formed in 1926, facilitated the interchange of information and research through a single agency at Geneva. At every turn, 
functionalists strove doggedly to extend and toughen links of daily dependency throughout the modern state system.

In the end, the most striking feature of the functionalist strategylike the legalist and reformist alternatives-was an essential modesty. Not one intended to change the independent basis of the American world role. Not one challenged the structure of decision-making within the United States. ${ }^{30}$ On the contrary, each aimed only to modify Washington's definition of the American role in a way that would discipline European politics without jeopardizing American independence. The modesty of this ambition was the product of many factors. Intellectual uncertainty, calculations of political expediency and the hope of uniting a hodgepodge of contentious peace groups all acted to restrain the movement's ambitions and kept it from acting upon its highest expressions of principle. Yet perhaps the most powerful source of the movement's modesty was its abiding sense of nationalism. Nearly every peace activist believed that the American national experiment contained patterns of right conduct that were relevant to Europe's needs. Whether legal, spiritual or functional, the behavioral patterns at the base of the American experience seemed well designed to overcome the dangerous incalculability of Old World politics.

At bottom, the movement's confidence in the relevance of the American national experience was only part of its larger hope of founding world peace upon "a newer and higher conception of nationalism." 31 Most peace workers in the Twenties rejected the "sentimental internationalism" of the pre-war movement and disliked the exclusiveness that was inherent in Wilson's vision of national self-determination. Instead, they endeavored to create an international polity that fitted the peculiar needs of their unsettled times. Specifically, post-war peace leaders sought to institute a world order that would accommodate cultural and political diversity at the same time as it ended the raw national egoism and conflicting Great Power imperialisms that had historically produced war. Seeking a positive alternative to rank egoism and Great Power tyranny, antiwar activists struggled to build a visible Higher Nationalism from the collective experiences of those modern peoples who recognized war as their common enemy. The need of civilized man, wrote Kirby Page, was "to carry one step higher a process which has long been operating." In plain terms, the issue was "whether or not militant nationalism, greedy imperialism and international anarchy are to lead nations on to further wars, or whether an era of international peace and justice shall be ushered in by outlawing war as a crime and by creating effective social machinery through which a new conception of nationalism may find expression." 32

With little doubt, nationalist sentiment was pervasive within American society in the 1920's. But it was not strictly a tribal affair. In the thinking of American peace leaders, nationalism expressed the reality of 
human diversity and the tenacity of human allegiance. Fascinated with its promise, they strove to channel its dynamism behind the functional and juridical alternatives to war that had long been vindicated by the American experience. Their hope for a Higher Nationalism was certainly grand. But it was not naive. Based upon a common interest and expanding through common institutions and common loyalties, it seemed in the Twenties to be the most humanly realistic solution to the calamity of modern total war. ${ }^{33}$

University of Toledo

\section{footnotes}

1. Judith N. Shklar, Legalism (Cambridge, 1965), 1-11, 104-105, 109-110, passim.

2. Robert Lansing, "Some Legal Questions of the Peace Conference," The American Journal of International Law, XIV (1920), 635-637. See also Codification of American International Law: Addresses by Charles Evans Hughes, James Brown Scott, Elihu Root, and Antonio Sanchez De Bustamente $Y$ Sirven (Washington, 1926), 51; the Report of the Executive Secretary, "A Review of the Peace Movement in America," in the 96th Annual Report of the Directors, American Peace Society, 1924, Box 5, Records of the American Peace Society, Swarthmore College Peace Collection; and "Suggestions for a Plan to Promote Peace Between Nations," The Advocate of Peace Through Justice, LXXXV (December, 1923), 403-404.

3. Lansing, 632; David Jayne Hill, "The Janina-Corfu Affair," The American Journal of International Law, XVIII (1924), 98.

4. Elihu Root, "The Steps of Progress," World Peace Foundation Pamphlets, VII (October, 1925), 526.

5. Theodore Woolsey, "Reconstruction and International Law," The American Journal of International Law, XIII (1919), 187; James Brown Scott, "The Foreign Policy of the United States," ibid., XV (1921), 232.

6. James Brown Scott, "America and Peace," The Advocate of Peace Through Justice, LXXXII (December, 1926), 667-676; unsigned editorial, "The Difference Between the United States and Europe, ibid., XCI (February, 1929), 69-73.

7. David Jayne Hill, "The Third Assembly of the League of Nations," The American Journal of International Law, XVII (1923), 79. Also see Elihu Root to Lothrop Stoddard, June 22, 1927, Box 142, Elihu Root Papers, Manuscript Division, Library of Congress; copy of Charles Evans Hughes address at the Pilgrims Dinner, London, July 21, 1924, Box 173, Charles Evans Hughes Papers, Manuscript Division, Library of Congress. Edgar Algernon (Lord) Robert Cecil, All the Way (London, 1949), 178.

8. "The Difference Between the United States and Europe," 72.

9. James Brown Scott, "A Governed World," The Advocate of Peace Through Justice, LXXXII (January, 1920), 2; Arthur Deerin Call, "Three Facts in American Foreign Policy," ibid., LXXXIII (April, 1921), 140-145.

10. Call, "A Review of the Peace Movement in America"; Call, "The Churches Can Promote International Peace," The Advocate of Peace Through Justice, LXXV (February, 1923), 47-49; “Our Country's Greatest Peace Society, ibid., XC (February, 1928), 78-80.

11. Unity, XCVII (July 12, 1926), 307.

12. Sherwood Eddy and Kirby Page, The Abolition of War: The Case Against War and Questions and Answers Concerning War (New York, 1924), 66.

13. Sidney Strong to William E. Borah, February, 1928, attached to Sidney Strong to Elinor Byrns, February 2, 1928, Box 20, Records of the Women's Peace Union of the Western Hemisphere, Swarthmore College Peace Collection.

14. Ibid., Press release, Box 3.

15. Frederick Libby, "Why an American Peace Movement," National Council for the Prevention of War News Bulletin, VII (July 1, 1928), 1.

16. Report of the General Secretary of the 13th Annual Meeting of the Board of Trustees, December, 1926, p. 5, Box 1, Records of the Church Peace Union, Swarthmore College Peace Collection.

17. The National Committee on the Cause and Cure of War, the more conservative of feminist peace organizations, was formed in 1924 by the suffragette leader Carrie Chapman Catt and "a large number of women who are not in the least satisfied with the situation they find themselves in and that is, carrying out the orders of the men managers of the different peace societies." Finding the movement's male leadership "both timid and incompetent," Mrs. Catt and her sympathizers moved to unite national women's organizations like the League of 
Women Voters and the Women's World Court Committee behind a feminist drive for peace. Carrie Chapman Catt to Lucia Ames Mead, January 9, 1924, Box 6, Lucia Ames Mead Papers, Swarthmore College Peace Collection.

18. The Women's International League for Peace and Freedom, for example, was willing by 1927 to support American accession to the League, "providing only that it does so with the understanding that the United States is exempt from any obligation to supply military forces, or to join in exerting military pressure in any case." The WIL also hoped that the American government, in applying for League membership, "would not only secure acceptance of this position, but would express its earnest desire to see the League renounce, or at least abstain from, all use of military sanctions." Emily Greene Balch to WIL members, April, 1927, Correspondence Box 5, Records of the Women's International League for Peace and FreedomU.S. Section, Swarthmore College Peace Collection. 118.

19. John Dewey, "Our National Dilemma," The New Republic, XXII (March 24, 1920),

20. For the fullest statement of the Outlawry position, see Charles Clayton Morrison, The Outlawry of War: A Constructive Policy for World Peace (Chicago, 1927).

21. National Council for the Prevention of War New Bulletin, IV (July 25, 1925), 1.

22. James T. Shotwell, "An American Locarno: Outlawing War As an Instrument of Policy," The Rotarian, XXXI (December, 1927), 7.

23. Raymond B. Fosdick to Felix Frankfurter, November 27, 1923, Raymond B. Fosdick Papers, Firestone Library, Princeton University. For the same idea expressed at length, see Raymond B. Fosdick, The Old Savage in the New Civilization (Garden City, 1928).

24. James $T$. Shotwell, "Preliminary Memorandum on the Organization to Prepare for a Disarmament Conference," September 15, 1925, Box 269, Tasker H. Bliss Papers, Manuscript Division, Library of Congress. Raymond B. Fosdick to Wallace Buttrick, April 11, 1924, Fosdick Papers. Or James T. Shotwell, "Are We at a Turning Point in the History of the World?," in The Report of the Division of Economics and History, Carnegie Endowment for International Peace, Yearbook, No. 16 (Washington, 1927).

25. James G. McDonald to Ivy Lee, ca. November, 1922, Box 1: General 1, James G. McDonald Papers, Herbert Lehman Collection, Columbia University.

26. Raymond B. Fosdick to Sir Eric Drummond, April 9, 1920, in Raymond Fosdick, Letters from the League of Nations, From the Files of Raymond Blaine Fosdick (Princeton, 1966), 123.

27. James G. McDonald, "Seven Roads to Peace," The Survey, LII (August 1, 1924), 497; James T. Shotwell, in Report of the Third Conference on the Cause and Cure of War, January, 1928, Box 1, Records of the National Committee on the Cause and Cure of War, Swarthmore College Peace Collection.

28. Charles Beard to Raymond Fosdick, May 20, 1922, Fosdick Papers.

29. Arthur M. Sweetser, Jr., to William Hamlin Childs, n.d., but ca. January, 1920, Box 13, Arthur M. Sweetser, Jr., Papers, Manuscript Division, Library of Congress.

30. Kirby Page was one of the few peace leaders to express an opinion on this subject, declaring that he saw "little hope of an intelligent foreign policy until there are drastic changes in personnel in Washington." But even he was contented that "such changes will take place within the very near future" through the normal rotation of electoral politics. Kirby Page to A. Barr Comstock, March 12, 1924, Box 2, Kirby Page Papers, Southern California School of Theology, Claremont, California.

31. Kirby Page, "Working Toward a Warless World," The Christian-Evangelist, LXII (June 11, 1925), 745. Esther Everett Lape, ed., The Ways to Peace: Twenty Plans Selected from the Most Representative of Those Submitted to the American Peace Award for the Best Practicable Plan by Which the United States May Cooperate with Other Nations to Achieve and Preserve the Peace of the World (New York, 1924), 44-46. Dr. Sidney Gulick, chairman of the Commission on International Justice and Goodwill of the Federal Council, referred to this objective as "the higher patriotism" or "Christian patriotism." Gulick, The Christian Crusade for a Warless World (New York, 1922), 45-47.

32. Kirby Page, Imperialism and Nationalism: A Study of Conflict in the Near East and of the Territorial and Economic Expansion of the United States (New York, 1925), 90.91.

33. Each of those components is vital to modern nationalism. See David M. Potter, "The Historian's Use of Nationalism and Vice Versa," American Historical Review, LXVII (July, 1962), 931-938. 